\title{
Water quality problems and management in rural areas of Limpopo Province, South Africa
}

\author{
J. O. Odiyo \& R. Makungo \\ Department of Hydrology and Water Resources \\ University of Venda, South Africa
}

\begin{abstract}
A study has been conducted to illustrate examples of water quality problems to vulnerable communities in Limpopo Province of South Africa (SA) and management practices and strategies. Pollution of water sources is a major threat to the scarce water resources in the province. This severely affects water quality and impacts negatively on public health particularly in remote rural communities that are rarely supplied with treated municipal water. Such communities rely on directly abstracted untreated water from rivers, boreholes, springs and rainwater harvesting. Cases of acute diarrhea and dental fluorosis have been shown to result from significant levels of fecal coliforms and fluorides respectively. The study shows that though water quality management strategies based on legal frameworks exist, lack of technical capacity and adequate finances, etc, at the municipality hinder efficient implementation.
\end{abstract}

Keywords: water quality, problems, management, rural areas.

\section{Introduction}

South Africa's scarce water resources are under threat due to extensive pollution. This affects the resource directly by making the water less acceptable for consumption (either for food production or any other identified use), depending on the extent, severity, and temporal nature of the pollution (Department of Environmental Affairs and Tourism [1]). For domestic use, typical pollutants of South Africa's water resources include effluent released by the growing industrial sectors, domestic and commercial sewage, acid mine drainage, faecal contamination linked to insufficient infrastructure and leaking sewers, domesticated animals grazing too close to water sources, agricultural runoff, and 
litter (Department of Environmental Affairs and Tourism [2]). Limpopo Province is an example of a predominantly rural and one of the poorest provinces in South Africa, with scarce water resources. Almost all the water resources in the province are nearly fully developed with all available water being already allocated and there are limited options for further resource development, due to the arid climate, unfavourable topography, sandy rivers as well as limited potential for increased groundwater abstraction (Limpopo DFED [3]). The scarce water resources in the province are under threat due to extensive pollution. This study illustrates examples of water quality problems to vulnerable communities in Limpopo Province of South Africa and management practices and strategies. Though a number of studies on water quality problems in Limpopo Province of South Africa have been conducted, there is still a need to document them, suggest possible remediation measures and management practices and strategies. This aids in minimizing water quality problems and possibly prevents any future pollution of the scarce water resources. Thus, the current study is aimed at describing water quality problems to vulnerable communities in Limpopo Province of South Africa, and providing possible remediation measures and management practices and strategies.

\section{Data acquisition and review}

Available information from different case studies on water quality problems in Limpopo Province and management strategies, legal and institutional frameworks were obtained from print and electronic media. The information was reviewed and inferences drawn particularly with regard to vulnerability and risks to water quality problems in Limpopo Province. An example of a typical current water use practice was photographed in the field to illustrate untreated water abstraction practices that have potential risks and vulnerabilities. The practical implementations of legal, institutional and strategic frameworks were also reviewed to determine their impact on water quality monitoring and management. Different intervention measures were proposed to manage specific health risks and vulnerabilities.

\section{Water quality problems to vulnerable communities in Limpopo Province}

There are indications that up to $27 \%$ of boreholes in Limpopo Province have water quality that is marginal or poor for domestic use and causing it to have a number of limitations for crop irrigation (FAO [4]). A number of studies have indicated that the main water quality problems include nitrates, fluorides, chlorides, total dissolved solids (TDS) and microbiological. Maisela et al. [5] assessed the physical and chemical quality of groundwater from 2036 boreholes used for domestic purposes in the former Northern Province (currently Limpopo Province). The study indicated that $42 \%$ of the boreholes assessed during the period 1970-1999 were not suitable for use without prior treatment due to high concentrations of nitrates, fluorides, chlorides and TDS. Results from the study 
indicate that the health of many people in rural areas may be at risk due to unacceptable levels of nitrates, fluorides, chlorides and TDS in borehole water. $50 \%$ of groundwater samples analyzed in groundwater region 3 (situated in Limpopo Province) were found to be unsuitable for human consumption mainly owing to high nitrate and fluoride concentrations (Vegter [6]). Water quality results from four monitoring stations of the Department of Water Affairs along the Luvuvhu River for a period of two years (2005-2007), showed that parameters such as COD, ammonia, turbidity and E-coli count consistently exceeded by far the limits given in SANS 241. All the above parameters are indicators of pollution in Luvuvhu River Catchment including, geology, land cover, livestock, agriculture, mining, industry, human settlements, and urban drainage.

A number of villages such as Siloam, Mandala, Milaboni, and Tshikombani located within Nzhelele River in the Limpopo Water Management Area are vulnerable to water quality problems. High levels of calcium, magnesium and nitrate in private boreholes, attributed to the agricultural practices and washing of clothes in the neighbourhood of the boreholes, have been found in groundwater in Siloam Village. High levels of calcium and magnesium increases the hardness of water. The total hardness of water is the sum of calcium and magnesium concentrations expressed as $\mathrm{mg} / \mathrm{L}$ (DWAF [7]). Hard water causes impairment of lathering and corrosion of household appliances (DWAF [7]). Hard water, however, has no impact on human health at concentrations below the maximum allowable limit of $200 \mathrm{mg} / \mathrm{L}$ of calcium carbonate (DWAF [7]).

Nitrates commonly generated from waste water, agricultural effluent from fertilizers and livestock feed-lots, waste disposal sites, urban sanitation, and cemeteries is the single most important reason for groundwater resources to be deemed unfit for human consumption in South Africa [4, 8]. High nitrate concentrations in groundwater occur mainly in a wide band stretching northeasterly from the Northern Cape, through the Northwest Province into the Limpopo Province (Tredoux [9]), which have large rural populations which are exposed to the risks involved with ingesting nitrate contaminated water (Tredoux et al. [10]). The rural communities in the Luvuvhu River Catchment use pit latrines for sanitation and the high concentrations of nitrates in these facilities are likely to contaminate groundwater. Nitrates contamination of groundwater is a serious threat to public health and high levels can lead to methamoglobinemia (blue baby syndrome), a disease found especially in infants less than six months but also can affect the adults (Chand et al. [11]). Tredoux et al. [10] confirmed the high nitrate and potassium concentrations in boreholes located in rural areas of the Limpopo, North West and Northern Cape Provinces. Groundwater in the Kutama and Sinthumule districts of Venda is also contaminated with nitrates derived from agricultural activities under a dry land cropping system (Connelly and Taussig [12]).

Mafenya [13] determined the presence in Nzhelele River at Siloam Village of microorganisms such as faecal coliforms, total coliforms, faecal enterococci, clostridium perfringens and heterotrophic plate counts at levels exceeding the recommended (DWAF [14]) standards for domestic water use. Information 
gathered from the local clinic in Tshikuwi Village in a study by Bessong et al. [15], indicated that 37 cases of diarrhoea in children aged less than five years and 23 cases of diarrhoea in individuals aged more than five years were recorded in June 2006. This was linked to the use of untreated surface and groundwater in Tshikuwi Village.

Mudau [16] investigated the effect of the location of pit latrines from the boreholes, soil type (geology) and terrain on groundwater quality in Mandala, Milaboni, Siloam and Tshikombani Villages in Nzhelele River Catchment. From the results obtained, the study concluded that the total microbial quality of borehole water in all the selected points was poor, unsafe and unacceptable for human consumption. This was because the high numbers of indicator organisms detected revealed that the microbial quality of borehole water sources were higher than the recommended minimum standard limits set by the South African Water Quality Guidelines in DWAF [14].

A survey of the microbiological quality of water from 194 boreholes (97 privately owned and 97 communal boreholes) in the rural Tshitale-Hlanganani area of the Limpopo Province, South Africa was carried out between August 2002 and August 2003 (Potgieter et al. [17]). The average counts for total coliforms, faecal coliforms, faecal enterococci and clostridium perfringens exceeded the South African recommended guideline limits. The microbial water quality from the Chunies River in Limpopo Province is unacceptable for domestic use throughout the course of the river due to faecal and coliform pollution. Many South African rural dwellers use untreated water domestically and are more at risk of the devastating effects of diarrhoea since diarrhoeacausing organisms may be transmitted as a result of poor quality of water, inadequate sanitation, and hygiene (Bessong et al. [15]). Diarrhoea which is a common complication of HIV infection is further compounded by lack of potable water supply and lack of good hygienic practices in most rural communities of the Limpopo Province (Obi and Bessong [18]). Studies such as, [18-20], highlighted a possible link between diarrhoea in HIV/AIDS patients (with compromised immunity) and poor water quality in rural communities in the Limpopo Province.

Groundwater quality can be affected on a local scale by the mineralogy of the geological formations in contact with the water (DWAF [21]). Groundwater supplied to communities north of Soutpansberg fails to meet domestic water quality standards because of high salinity (FAO [4]). The geology of Luvuvhu River Catchment has a potential to contribute to water pollution. The geology of the Soutpansberg Mountains, where the Luvuvhu River and its tributaries originate from, contains minerals such as copper, iron, refractory flint, salt, sillimate and coal according to literature review by Odiyo et al. [22]. The land uses (agriculture and human settlements) in the Luvuvhu River Catchment have the potential for causing water pollution. The irrigated agricultural schemes mostly produce fruits and vegetations which require a lot of pesticides and fertilizers for their production. Fertilizers containing inorganic nitrates, originating from fertilizers containing potassium nitrate and ammonium nitrate, can be hazardous at high concentrations and can ultimately be detrimental to the 
health of children, nursing mothers, the elderly and those with compromised immune systems (Tredoux and Talma [23]).

A survey done in Siloam Village by Mashai [24] shows that of the $87 \%$ of the households that use groundwater, $85 \%$ had members with mottled teeth. $50 \%$ of school learners between the ages of 11-14 also had mottled teeth in 2007, due to high levels of fluorides. A typical example of untreated groundwater abstractions for domestic use is shown in Figure 1.

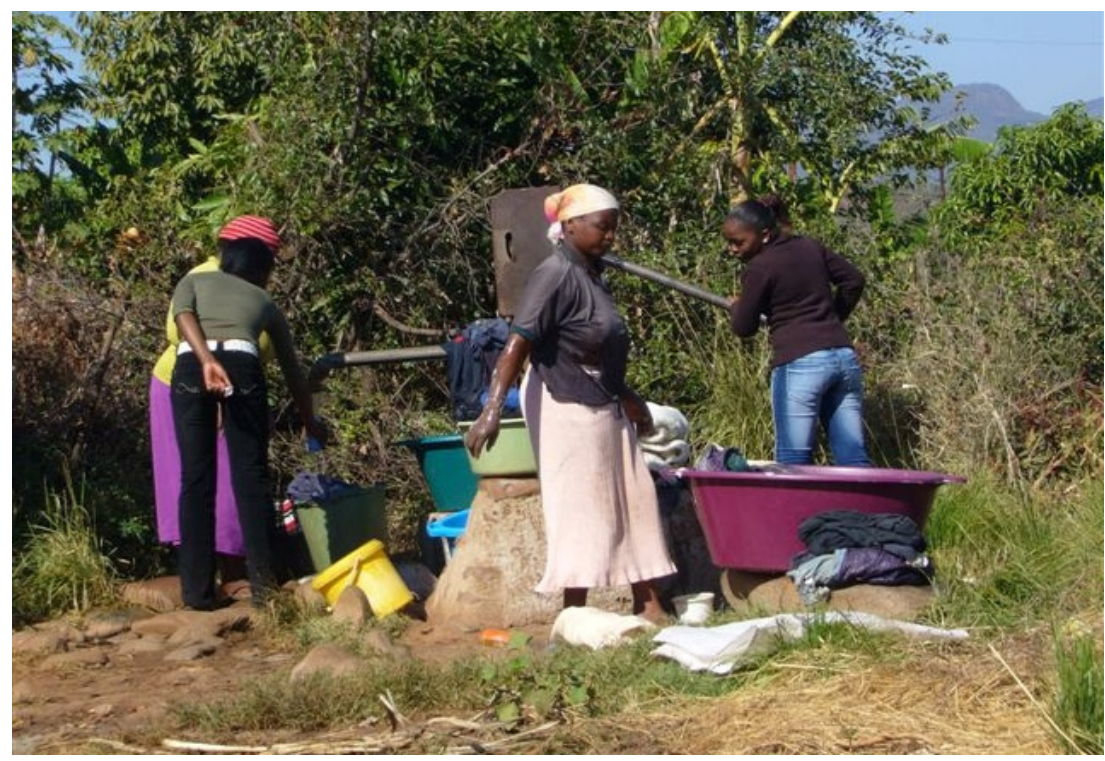

Figure 1: Water abstraction from a borehole (taken from Siloam Village on 24/03/2007).

Aneck-Hahn et al. [25] confirmed the oestrogenic activity due to endocrine disruption chemicals (EDC) in drinking water from rural areas in the Waterberg District, Limpopo Province, South Africa. Water in the rural areas is often contaminated with a complex mixture of toxic compounds originating from nearby industries, agriculture and households which are believed to disrupt normal endocrine function in humans and animals (Aneck-Hahn et al. [25]). The study argued that EDC exposure partly contributes to the high incidence of stunted growth in the study population.

\section{Possible remediation measures}

In typical rural areas where they cannot afford the conventional water treatment technologies and do not have adequate skills to operate and/or maintain them, household water treatment is an alternative means of providing potable drinking water. For example, for removal of fluorides from drinking water, defluoridation normally accomplished by adsorptive and precipitation processes can be 
conducted. A number of defluoridation methods have been documented in studies such as, [26-29], among others. Feenstra et al. [29] identified the nalgonda process, bone charcoal and calcined clay as low cost methods that can be applied in treating water for small scale domestic use particularly in rural areas. Piñón-Miramontes et al. [30] reported the use of cake alum as defluoridator, which is a low cost method that can also be applied in rural areas. These methods can be used to reduce the high fluoride concentrations in groundwater in rural areas.

For reducing microbial organisms, Obi [31] proposed physical methods that can be used for treatment of household water in rural communities. These methods include storage and settlement, boiling and filtration. Schutte [32] also recommended boiling of water before use, use of home bleach and other chlorine compounds, exposure to sunlight, use of home filters (followed by disinfection) and use of natural coagulants (followed by disinfection). Any of these methods can be used to treat water in rural villages before domestic use depending on what each household prefers or can afford. This requires that the rural communities be educated on point of use or points of abstraction treatment of water to potable standards.

\section{Management practices and strategies}

Solving water quality problems requires strategies to prevent, treat, and remediate water pollution. Water resource management, including water quality management, is an exclusive National competency. As such, water quality management is the responsibility of the Minister of Water Affairs. The Department of Water Affairs' Water Quality Management function consists of the:

○ Department's Directorate of Water Quality Management, which provides policy development, capacity building, specialist support, authorization and audit services at a strategic level;

○ Department's nine Regional Offices, which provide policy implementation, operation, control and monitoring services at an operational level; and

○ Department's Institute for Water Quality Studies, which provides a scientific support service.

South Africa has extensive and comprehensive policy, legal, technical and institutional frameworks to support water quality monitoring and management. These include National Constitution (Act 108 of 1996), National Water Act (No. 36 of 1998), Water Services Act (No. 108 of 1997), Municipal Structures Act (No. 117 of 1998), [21, 33, 34], amongst others.

The South African National Constitution (Act 108 of 1996) states that every citizen has the right to access adequate water that is not harmful to health. The constitution says "it is every person's right to have access to clean water". This places an obligation on those charged with the provision of water to communities 
at all times and implies that the quality at the point of consumption should be monitored closely. The Water Services Act (No. 108 of 1997) gives substance to constitutional requirements with respect to access, national norms and standards and institutional framework for provision of water services. It states that drinking water quality should comply with prescribed National Drinking Water Standards (SANS 241 Drinking Water Specification) and requires consumers Services Regulations (Regulation 16 of Section 9 of the Water Services Act) to monitor consumer comments and complaints, thereby providing valuable information on potential problems that may not have been identified. The Water Services Act, therefore, makes it mandatory that consumers including rural communities be involved in water quality monitoring and management.

The National water Act (No. 36 of 1998) is the principal legal instrument in South Africa and contains comprehensive provisions for the protection, use, development, conservation and management and control of South Africa's water resources. Municipal Structures Act (No. 117 of 1998) provides for functions and powers of municipalities and other local government structures in provision of services including water.

The Strategic Framework for Water Services (DWAF [33]) encompasses a number of tiered planning strategies that are inter-linked so as to inform one another; and incorporates a national implementation strategy which covers both the management and allocation of water. Essentially the implementation strategy is described in 2 pieces of legislation: the National Water Resource Strategy (DWAF [21]) and the Catchment Management Strategy (DWAF [35]). It sets out a comprehensive approach with respect to the provision of water services in South Africa, ranging from small community water supply and sanitation schemes in remote rural areas to large regional schemes supplying water and wastewater services to people and industries in largest urban areas (DWAF [33]).

At the local government level, the primary responsibility for ensuring the provision of safe drinking water rests with Water Services Authorities (WSAs). The legal responsibility of WSAs as outlined in Hodgson and Manus [36] are to:

- Monitor the quality of drinking water provided to consumers

- Compare the results to national drinking water standards (SANS 241)

- Communicate any health risks to consumers and appropriate authorities

The National Water Resources Strategy (DWAF [21]) describes the strategies, objectives, plans, guidelines and procedures and the institutional arrangements necessary for the protection, use, development, conservation, management and control of South Africa's water resources.

WSAs fail to comply with compulsory national standards for the quality of potable water (Mackintosh et al. [37]). In recognition of these challenges, a Drinking Water Quality Framework was proposed for South Africa to enable effective management of drinking water quality to protect public health (DWAF [34]). The framework promotes an understanding of the entire water supply system, the events that can compromise drinking water quality and the operational control necessary for optimizing drinking water quality and 
protecting public health. However, the framework also recognizes the challenges facing WSAs in South Africa, and advocates a continual incremental improvement approach towards long-term targets (Hodgson and Manus [36]). The framework was also formulated due to the need for immediate action, the perceived lack of resources and capacity within certain WSAs to conduct the required drinking water quality monitoring and management, and the perceived lack of understanding of these WSAs regarding governance requirements, responsibilities and accountabilities.

Water quality problems arising from developing communities can be managed, using an integrated approach based on scientific investigation, community involvement and engineering expertise, in order to minimize pollution problems to the extent that the receiving water environment objectives can be maintained on a sustainable basis (Pretorius and de Villiers [38]).

A study by Palaniappan et al. [39] noted that "Despite these reforms, data from 2004 showed that only less than 50 percent of water service providers had drinking water quality monitoring programmes in place. The government also developed the "Blue Drop" status, which is awarded to water service providers who are at or above 95 percent compliance with standards. In 2009, 100 percent of the municipal authorities had water quality monitoring programmes in place, though only 18 municipalities have been awarded Blue Drop status out of over 150 municipalities." Thus, though water quality management strategies exist, lack of technical capacity and adequate finances, etc, at the municipality level hinder efficient implementation.

Numerous water-monitoring programmes are being undertaken by the different spheres of government. Examples include the DWAF's national water quality and microbial monitoring programmes, the River Health Programme and monitoring by local authorities and service providers (Department of Environmental Affairs and Tourism [1]). DWAF [40] developed a water strategy and 5-year work plan for the Limpopo Province which includes high-level strategic objectives for the province. One of the strategic goals is to ensure water resource allocation and development to meet the needs of the province which also focuses on improving water quality and its management.

\section{Conclusions}

The study reviewed water quality problems in rural areas of Limpopo Province, South Africa and gave examples of communities that are vulnerable to such pollution and the associated health threats. Land use activities such as effluent released by the growing industrial sectors, domestic and commercial sewage, acid mine drainage, faecal contamination linked to insufficient infrastructure and leaking sewers, improperly sited sanitation systems, domesticated animals grazing too close to water sources, agricultural runoff, and litter and natural sources such as geology contribute to water pollution. Cases of acute diarrhea and dental fluorosis in rural areas have been shown to result from significant levels of fecal coliforms and fluorides respectively. Household treatment of water for domestic use has been found as an alternative way for providing 
potable drinking water. The review showed that there are extensive and comprehensive policy, legal, technical and institutional frameworks to support water quality monitoring and management in South Africa. However, there is inefficient implementation due to lack of technical capacity and adequate finances, etc, at the municipality level.

\section{References}

[1] Department of Environmental Affairs and Tourism. South Africa Environment Outlook, A report on the state of the environment. Department of Environmental Affairs and Tourism, Pretoria, 2006.

[2] Department of Environmental Affairs and Tourism. State of the freshwater systems and resources, 4, Department of Environmental Affairs and Tourism, South Africa, 1999.

[3] Limpopo DFED. Limpopo State of the environment report (Phase 1). Limpopo Department of Finance and Economic Development, South Africa, 2004.

[4] FAO. Drought impact mitigation and prevention in the Limpopo River Basin, A situation analysis, Food and Agriculture Organization of the United Nations, Rome, 2004.

[5] Maisela, L.L., Ncube, E. and Kühn, A. The physical and chemical quality of borehole water used for domestic purposes in the Northern Province, WISA 2002 Biennial Conference. Durban, 2002. http://www.ewisa.co.za/misc/WISAConf/default2002.htm.

[6] Vegter, J.R., Hydrogeology of Groundwater - Region 3: Limpopo Granulite-Gneiss Belt, Water Research Commission (WRC) Report No. TT136/00, 2001.

[7] Department of Water Affairs and Forestry (DWAF), Department of Health \& Water Research Commission. Quality of domestic water supplies, Assessment Guide, 1, $2^{\text {nd }}$ Edition, WRC Report No. TT 101/98, Water Research Commission, Pretoria, South Africa. 1998.

[8] Tredoux, G., Engelbrecht, J.F.P. and A.S. Talma. Nitrate in groundwater in southern Africa. New approaches characterizing groundwater flow, eds. Seiler \& Wohnlich, Swets \& Zeitlinger, Lisse, pp. 663-666, 2001.

[9] Tredoux, G., Preliminary investigation of the nitrate content of groundwater and limitation of the nitrate input, WRC Report No 368/1/93, Pretoria, 1993.

[10] Tredoux, G., Talma, A.S. and Engelbrecht, J.F.P. The increasing nitrate hazard in groundwater in the rural areas, WISA 2000 Biennial Conference, Sun City, South Africa, 2000.

[11] Chand, S, Ashif, Y., Zargar M.Y., and Ayub, B.M. Nitrate Pollution: A menace to human, soil, water and plant. Universal Journal of Environmental Research and Technology, 1, pp. 22-32, 2011.

[12] Connelly, R.J. and Taussig, D. Nitrate contamination of groundwater in the Kutama and Sinthumule districts of Venda, South Africa, Groundwater 
Quality, eds. Nash, H. and McHall G.J.H., Chapman and Hall, pp. 145-151, 1995.

[13] Mafenya, H., A microbial assessment of potable water source such as ground and surface water in Siloam Village, Limpopo Province of South Africa, unpublished Honours research dissertation, University of Venda, South Africa, 2007.

[14] Department of Water Affairs and Forestry (DWAF). South African water quality guidelines, 1: Domestic water use, $2^{\text {nd }}$ Edition, Pretoria, 1996.

[15] Bessong, P.O., Odiyo, J.O., Musekene, N.J. and Tessema, A. Spatial distribution of diarrhoea and microbial quality of domestic water during an outbreak of diarrhoea in the Tshikuwi community in Venda, South Africa. Journal of Health Population Nutrition, 27(5), pp. 652-659, 2009.

[16] Mudau, T.C. Effects of pit latrines location on groundwater quality of Nzhelele Villages within Limpopo Province, South Africa, unpublished Honours research dissertation, University of Venda, South Africa, 2011.

[17] Potgieter, N., Mudau, L.S. and Maluleke, F.R. Microbiological quality of groundwater sources used by rural communities in Limpopo Province, South Africa. Water Science and Technology, 54(11-12), pp. 371-377, 2006.

[18] Obi, C.L. and Bessong, P.O. Diarrhoeagenic bacterial pathogens in hivpositive patients with diarrhoea in rural communities of Limpopo Province, South Africa. Journal of Health Population Nutrition, 20(3), pp. 230-234, 2002.

[19] Obi, C.L., Ramalivhana, J., Momba, M.N.B. and Igumbor, J. Scope and frequency of enteric bacterial pathogens isolated from HIV/AIDS patients and their household drinking water in Limpopo province. Water $S A, 33(4)$, 539-548, 2007a.

[20] Obi, C.L., Ramalivhana, J., Momba, M.N.B., Onabolu, B., Igumbor, J.O., Lukoto, M., Mulaudzi, T.B., Bessong, P.O., van Rensburg, E.L., Green, E. and Ndou, S. Antibiotic resistance profiles and relatedness of enteric bacterial pathogens isolated from HIV/AIDS patients with and without diarrhoea and their household drinking water in rural communities in Limpopo Province South Africa. African Journal of Biotechnology, 6(8), pp. 1035-1047, $2007 \mathrm{~b}$.

[21] DWAF. National Water Resource Strategy. Department of Water Affairs and Forestry, South Africa, First Edition, 2004.

[22] Odiyo, J.O., Makungo, R. and Muhlarhi, T.G. Investigating the impacts of geochemistry and agricultural activities on groundwater quality in the Soutpansberg fractured rock aquifers, Groundwater Conference, Somerset West, Cape Town, South Africa, 2009.

[23] Tredoux, G. and Talma, A.S. Nitrate pollution of groundwater in southern Africa, eds. Xu, Y. and Usher, B., Groundwater pollution in Africa, Taylor \& Francis/Balkema, Leiden, The Netherlands, pp. 15-36, 2006.

[24] Mashai, N.P.D. Monitoring fluorides concentrations and determining their impacts on human health at Siloam Village in Limpopo Province of South 
Africa, unpublished Honours research dissertation, University of Venda, South Africa, 2007.

[25] Aneck-Hahn, N.H., Bornman, M.S. and de Jager, C. Oestrogenic activity in drinking waters from a rural area in the Waterberg District, Limpopo Province, South Africa. Water SA, 35(3), pp. 245-251, 2009.

[26] Srimurali, M., Pragathi, A., and Karthikeyan, J. A study on removal of fluorides from drinking water by adsorption onto low-cost materials. Environmental Pollution, 99, pp 285-289, 1998.

[27] Chidambaram, S., Ramanathan, A.L. and Vasudevan, S. Fluoride removal studies in water using natural materials, Technical note. Water $S A$, 29(3), pp 339-344, 2003.

[28] Meenakshi, M. and Maheshwari, R.C. Fluoride in drinking water and its removal. Journal of Hazardous Materials, B137, pp. 456-463, 2006.

[29] Feenstra, L., Vasak, L. and Griffioen J. Fluoride in groundwater: Overview and evaluation of removal methods, International Groundwater Resources Assessment Centre Report nr. SP 2007-1, 2007.

[30] Piñón-Miramontes, M., Bautista-Margulis, R.G., and Pérez-Hernándeza, Y. Removal of arsenic and fluoride from drinking water with cake alum and a polymeric anionic flocculent. Fluoride, 36(2), pp. 122-128, 2003.

[31] Obi, C.L. (2004) Treatment of household drinking water for the removal of faecal bacteria causing water borne diseases in rural communities, National Microbial Monitoring Programme, DWAF, Pretoria.

[32] Schutte, C.F. Quality of domestic water supplies, 4: Treatment Guide, $1^{\text {st }}$ Edition, WRC Report No. TT 129/00, Water Research Commission, Pretoria, South Africa, 2002.

[33] DWAF. Strategic framework for water services, Department of Water Affairs and Forestry, South Africa, 2003.

[34] DWAF. A drinking water quality framework for South Africa. Department of Water Affairs and Forestry, South Africa, 2005.

[35] Department of Water Affairs and Forestry (DWAF) The Catchment Management Strategy, http://www.DWA.gov.za//documents/other/CMA/ CMSGuidelineFeb07, 2007.

[36] Hodgson, K. and Manus, F. A drinking water quality framework for South Africa. Water SA, 32(5), pp. 673-678, 2006.

[37] Mackintosh, G., Delport, E., Ramba, M. and Genthe, B. Drinking-water quality management procedures for rural communities - South African Case Studies - WISA 2000 Biennial Conference, Sun City, South Africa, 2000. http://www.ewisa.co.za/misc/WISAConf/default2000.htm.

[38] Pretorius, E. and de Villiers, G.D.T. An integrated approach for the development of a cost-effective strategy for managing stormwater quality effects of a developing community in the south-eastern suburbs of Bloemfontein, South Africa, WISA 2000 Biennial Conference, Sun City, South Africa, 2000. http://www.ewisa.co.za/misc/WISAConf/ default2000.htm. 
[39] Palaniappan, M., Gleick, P.H., Allen, L., Cohen, M.J., Christian-Smith, J. and Smith, C. Clearing the Waters, a focus on water quality solutions, United Nations Environment Programme, 2010.

[40] DWAF. Limpopo water strategy and 5-year work plan, Department of Water Affairs and Forestry, South Africa, 2006. 